\title{
Article \\ The Impact of the VUCA Environment on the Digital Competences of Managers in the Power Industry
}

\author{
Anna Nowacka ${ }^{1, *(D)}$ and Magdalena Rzemieniak ${ }^{2, *(D)}$ \\ 1 Faculty of Management, Czestochowa University of Technology, 19B Armii Krajowej Street, \\ 42-200 Czestochowa, Poland \\ 2 Faculty of Management, Lublin University of Technology, Nadbystrzycka 38D Street, 20-618 Lublin, Poland \\ * Correspondence: anna.nowacka@pcz.pl (A.N.); m.rzemieniak@pollub.pl (M.R.)
}

check for updates

Citation: Nowacka, A.; Rzemieniak, M. The Impact of the VUCA Environment on the Digital Competences of Managers in the Power Industry. Energies 2022, 15, 185 https://doi.org/10.3390/en15010185 Academic Editors: Joanna Kulczycka and Marek Dudek

Received: 21 November 2021 Accepted: 22 December 2021 Published: 28 December 2021

Publisher's Note: MDPI stays neutral with regard to jurisdictional claims in published maps and institutional affiliations.

Copyright: (C) 2021 by the authors. Licensee MDPI, Basel, Switzerland. This article is an open access article distributed under the terms and conditions of the Creative Commons Attribution (CC BY) license (https:// creativecommons.org/licenses/by/ $4.0 /)$.

\begin{abstract}
The article presents the scope of issues related to the impact of the VUCA (volatility, uncertainty, complexity, ambiguity) environment on digital competences of management staff in power companies. Each company has to deal with its own individual and personalized VUCA world typical for the power industry. Unfortunately, some organizations are not aware of its existence, and therefore they do not identify the signals coming from the external environment while still working according to the developed patterns. The VUCA approach requires changing the competency model in enterprises and focusing on its strengths. On this basis, the research problem regarding power enterprises was formulated. The problem discussed in the article below concerns the undefined and undefined influence of the VUCA environment on the emerging digital competences of managers. In connection with the identification of the research problem in this area, an attempt was made to define the aim of the study, which is to determine the impact of the connections of the VUCA world with digital competences of managers in the energy sector. To solve the research problem, quantitative research was carried out on a randomly selected sample of managers. It has been shown that leaders are more or less aware of the existence of the VUCA world. As key competences, they mention the ability to develop and adapt digital technologies to the needs of the organization or the ability to flexibly switch thinking between various problems. The novelty of the work is the identification of the connections between the VUCA world and competences and the provision also through the prism of artificial intelligence. The existence of links between the VUCA environment and digital competences was indicated, and the use of VUCA as a determinant of the impact on changing the perception of employees was analyzed.
\end{abstract}

Keywords: VUCA; competences; power industry

\section{Introduction}

Increasingly, the acronym VUCA (volatility, uncertainty, complexity, ambiguity) is used to describe dynamic changes in the external environment that have a direct or indirect impact on the functioning of enterprises [1]. The consequence of multidimensional transformations is the internal reorganization of organizational units, and thus the transformation of competency models, as well as defining the key behaviors and skills of employees.

The world of VUCA is characterized by volatility, uncertainty, complexity, and ambiguity. The most accurate descriptions are: quick and chaotic changes, lack of standards, or the constant outdating of plans and projects. In the 21st century, VUCA attacked the corporate and business world ruthlessly. Consequently, one of the main effects is the problem of defining and understanding the surrounding world by managers (not only in the power sector) [2].

Contemporary resources focus on technical and technological skills, as well as on the attempts made to think in an agile manner. In all of this, digitization of processes, which eliminates "human work", plays a major role. From the VUCA perspective, the possibilities 
of preparing many scenarios of a situation, managing a dispersed team, or understanding IT systems are becoming more and more crucial in understanding the idea of this dogma. In a turbulent economic environment, marked by multiple challenges and changes at every step, organizations must adapt their management system in order to maintain or even increase their productivity, as well as their competitive advantage. All of the activities carried out within an organization are based on a series of managerial decisions, dependent on each other, by which the objectives and the modalities of action are determined, ensuring an economic-financial balance [3].

Leadership agility and adaptability have become skills that are required among leaders to be successful in the VUCA world. According to Horney, Pasmore, and O'Shea: "Leaders need to make continuous changes to people, processes, technology, and structure. This requires flexibility and speed in making decisions" [4]. Alongside these discussions of VUCA are various ideas about how executives should guide their organizations in dealing with turbulence and attempts to characterize how employees of all levels can best deal with increasingly frequent change or uncertainty. A prevailing idea that has emerged is that agility (at the person, team, and organizational levels) is necessary for effective management of VUCA [5].

Leaders and their teams are most vulnerable to the volatility and chaos of the VUCA environment. Managers are expected to be leaders, as well as bosses, managers, or presidents in one person. In such situations, leaders must very often use competences that they have not used before. The identification of attitudes and behaviours that are currently used is determined according to VUCA. The aim of the article is to identify key digital competences of managers that have changed the prism of their work.

The focus of the article is to present the essence of VUCA and its impact on the competency model in enterprises. The purpose of the article is to determine the impact of the world of VUCA on digital competences of managers of the power industry in the Masovian Province. The article is based on the quantitative research conducted by the authors on a randomly selected sample of respondents. The research was aimed at identifying the links between the respondents' understanding of the existence of the VUCA environment and finding links between the digital competences of managers. In many cases, managers were not aware of the existence of VUCA, but use new digital skills. The article presents anonymous quantitative research conducted via a survey in the form of an electronic questionnaire on a randomly selected sample of respondents. The respondents replied electronically to the questions asked in the questionnaire.

The article reviews the current literature on the subject and presents the methodology of the research process and its results along with the discussion of the results and final conclusions.

The article consists of six sections. First, the review of the literature of acronym VUCA and digital competences. Second, the materials and methods of the research carried out are described. Then, the results of quantitative research are presented. In the next steps, the sections of discussion and summary of the entire article.

The authors' contribution to the article is as follows:

- A detailed analysis of the research subject was carried out.

- $\quad$ Reference was made to the contemporary literature of the discussed topic.

- $\quad$ Proprietary quantitative research was carried out on a selected sample of respondents.

- $\quad$ Research results are valuable in management and quality sciences, presenting important relationships between the VUCA world and managers' competences.

\section{Literature Overview}

The word VUCA was defined by the teachers of the United States Army War College as a response to the ongoing changes and implications in the preparation of military commanders in the 1990s [3,6-8]. The abbreviation presented the features describing the environment in a simple way, defining it as: uncertain, unstable, ambiguous, and also complex [9]. After the incident that took place on 11 September 2001 in New York involving 
the Word Trade Center, the US Army became known as "VUCA University", which in fact meant consent to long-term changes not only in America but also around the world [1,10]. This situation determined the existence of the acronym, which quickly evolved and found reference in business [11,12]. VUCA was implemented by managers to easily define the chaotic and continuously changing business environment that marked the entry into "new normal" $[8,13]$.

VUCA combines four different types of challenges in one word, to which there are four different types of responses [14,15]. The acronym VUCA comes from the words:

- VOLATILITY-it occurs in situations when the established pattern of action is changed or violated. The size of the changes that occur cannot be rationally predicted [16]. Very often there are new ideas, ideas that employees are not sure about. This is due to the unexamined and non-obvious solutions, while the perception in the case of old solutions begins to fail [17]. The factors determining volatility in business include: digitization, global competition, or any innovations in business models [18].

- UNCERTAINTY - associated with the lack of a sense of control and uncertainty about what will happen in the near future. Unstable conditions make it impossible to rely on the developed patterns as indicators of forecasting future results [19]. The consequence of such situations is difficulty with making the right business decisions. Conditions that can be defined as uncertain affect a relatively low level of awareness, and hence the understanding and acceptance of the situations [14]. Organizational uncertainty directly affects the length of the planning process [20].

- COMPLEXITY - which becomes evident when many volatilities appear. There are many reasons for the occurrence of an event, as well as causes and effects that are not clear in their specifics [21]. The difficulty of understanding the relationship between the components does not have a cause-effect chain. Chaos and turmoil surround enterprises. The complexity and multiplex nature of the causes seem to be infinitely long, and this consequently means that they are impossible to be defined [22].

- AMBIGUITY - in most cases it involves business ambiguity. This is the case where there are many possibilities of choices for one situation [23]. These are a type of "scenarios" that will blind companies that are unable to prepare to be agile. Enterprises that will remain in their conservative status quo will not be able to succeed in an ambiguous future [24,25].

Each of the VUCA components causes chaos and turbulence in the context of strategic and operational management of leaders in their daily duties [26]. Management meets the VUCA world with greater or lesser awareness of it. Attached to daily, repeating patterns of action, they lose their vigilance and intuition to predict events, which in turn results in a greater number of mistakes [27]. The limitations of empirical research are needed to validate, confirm and further elucidate specific mechanisms and values in VUCA. Organizations need to move beyond espousing a value of curiosity to deliberately and effectively cultivating and supporting it within their employees [28].

Figure 1 shows the relationship between the four components of VUCA: volatility, uncertainty, complexity and ambiguity. They form a mutual cause-effect sequence in which one category does not exist without the other. The less known the situation and the results of actions, the more unknown and incomprehensible the world of VUCA is.

It directly translates into strategic and accurate decision-making among leaders [29]. On the other hand, the greater the perception and self-awareness of the situation as well as the ability of forward thinking of managers, the more VUCA becomes the world (clear and understandable) $[28,30]$.

In their research, B.E. Baran and H.M. Woznyj provided three sets of interrelated activities that the management and key decision makers can use to guide their organizations through turbulence: identify their VUCAs, define obstacles in agility, and implement agilityenhancing practices. The authors concluded that these three sets of actions are critical to the sustained success of any team or organization in turbulent conditions. The authors presented synthesized conclusions from a study of a diverse group of 1152 leaders and 
provided tools for leaders who wish to manage VUCA in their environments by building agility around them by others. Researchers also integrated their own findings with relevant management and organizational behavior research to ensure evidence-based and sciencebased practices [5].

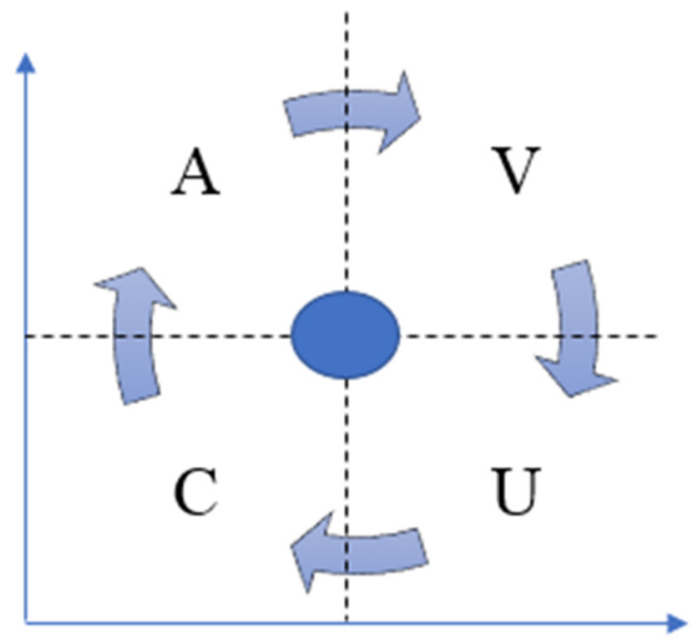

Figure 1. Mutual interaction of VUCA components.

The condition of the company's success is, above all, the ability to follow the changing market environment on a global, not local, level, in an agile way. Companies must adapt the pace of changes that will respond to the increasingly newer needs of internal and external stakeholders and clients. Pace is an indicator that directly affects the speed and accuracy of decisions made by people involved in the decision-making process. The market is moving towards the implementation of innovative digitization processes or the digitization alone [31]. It is a direction of development that requires a qualified managerial staff with specific skills and competences [32]. Although the studies by B. Bader, T. Schuster, and M. Shaffer confirm the limitations of validation and the need to confirm the influence of further mechanisms of the VUCA environment [33].

According to R. Kozierski: "Success is achieved by organizations that notice and appreciate the changes taking place and give up the traditional approach to market activities and the functioning of the organization" [34]. Looking from the VUCA perspective, apart from hard competences, which include: technical skills related to new technologies (hard qualifications), soft competences are becoming increasingly more important [35]. Behaviors that are related to the use of knowledge by employees, i.e., know-how. These are attitudes and personality traits which include: creativity, interpersonal and communication skills, as well as teamwork skills $[36,37]$. To sum up, substantive knowledge and hard competences are not sufficient to develop innovations that affect the business success of a company (they are and will be complemented by soft competences) [38].

It seems that the key competences in the VUCA world are adaptation to market expectations and anti-fragility (resistance to shocks). The latter means a stable situation of an enterprise in conditions of volatility and chaos. According to N. Taleb: "some things need shocks; they grow and thrive under the influence of volatility, randomness, disorder and stress; adventures, risk and uncertainty are their element" [39]. This applies to enterprises that perceive uncertain market conditions as a factor in their growth, while uncertainty as a challenge, which is not obvious in the VUCA world. These literature and empirical observations are confirmed by P. Tudorache, L. Ispas et al. Researchers found that developing artificial intelligence (AI) as a factor that supports leaders in the decision-making process and increasing organizational flexibility, building their agility to be flexible regardless of the context, or creating the necessary conditions to shape the expeditionary mindset of leaders. With high-quality skills at their disposal, leaders will not only be able to understand current decision-making environments, but also visualize 
those that will emerge in the future, regardless of their physiognomy [40]. AI and machine learning are contemporary business tools that provide valuable information on various areas of the company's operations and ensure sustainable growth. Huge amounts of data produced by enterprises require processing, classification and analysis. Various entities, ranging from start-ups to global leaders, are researching how artificial intelligence and increasingly advanced machine learning algorithms can be used for many applications, including skills development in the context of VUCA.

VUCA is both a problem for managers and a challenge at the same time. It is a problem with systematizing such a model of accurate competences that will strictly correspond to VUCA while being a challenge when it comes to departing from old patterns and schemes, and focusing on reorganization and eliminating constantly repeating mistakes. This is confirmed by the research of R. Elkington [41].

The Table 1 below presents the competences that directly correspond to the VUCA world. They are presented as an answer to each word of the VUCA acronym. A manager aware of what surrounds him/her will see a wide perspective of vision, understand the situations that surround him/her and react to them quickly, communicate in a simple, clear and transparent manner, as well as based on agile resource management [42].

Table 1. Assignment of managerial competences to VUCA.

\begin{tabular}{|c|c|}
\hline VUCA & Description Competences \\
\hline $\begin{array}{l}\text { VISION } \\
\text { The answer to Volatility }\end{array}$ & $\begin{array}{l}\text { Defines the vision of the project taking into account the } \\
\text { target description. This approach makes it possible to } \\
\text { determine a certain trend in terms of volatility. }\end{array}$ \\
\hline $\begin{array}{l}\text { UNDERSTANDING } \\
\text { The answer to Uncertainty }\end{array}$ & $\begin{array}{l}\text { A stakeholder's feedback is actually the answer to an } \\
\text { uncertain situation. In the line of reasoning, it means open } \\
\text { communication throughout the enterprise regard-less of } \\
\text { the existing organizational structure. It is aimed at a } \\
\text { simple flow of information determining quick decisions. }\end{array}$ \\
\hline $\begin{array}{l}\text { CLARITY } \\
\text { The answer to Complexity }\end{array}$ & $\begin{array}{l}\text { It focuses on the management system in the enterprise } \\
\text { that is understandable to employees. It results in the } \\
\text { creation of procedures and process descriptions that are } \\
\text { understandable to employees. As a consequence, } \\
\text { everyone is aware of the course of action, regardless of the } \\
\text { chaos that appears in the external environment. }\end{array}$ \\
\hline $\begin{array}{l}\text { AGILITY } \\
\text { The Answer to Ambiguity }\end{array}$ & $\begin{array}{l}\text { It is a competence that largely supports managers in } \\
\text { ambiguous conditions. It al-lows for accurate } \\
\text { identification of phenomena through experiments. Instead } \\
\text { of discussing it, it's easier to create a prototype and be able } \\
\text { to test it. }\end{array}$ \\
\hline
\end{tabular}

Threats in adapting new competences may include: adaptation gap (requiring adaptation to changes), social exclusion and the so-called digital divide. The last risk is related to the limited following of changes and technology development, and not access to resources. The "black swan" (which means it is a phenomenon that is unexpected and has great consequences) will affect those enterprises and those managers who will be burdened with the occurrence of the above-mentioned risks [43].

Digital and technical competences are included in the group of hard skills. However, digital competences are becoming more and more important. The above does not only cover data analysis or a programming language, but the broad scope of problem solving or cybersecurity, which is becoming more and more important [44].

According to McKinsey, there are three groups of competences in the labor market:

- Social competences, which include: HR management, negotiations, cooperation, as well as emotional intelligence; 
- Cognitive competences is a group consisting of cognitive flexibility, critical thinking, creativity and solving difficult problems;

- Digital and technical competences (i.e., understanding and developing advanced digital technologies and knowing how to adapt them to the needs of enterprises).

Research shows that by 2030 employees will spend $40 \%$ more time using digital competences. When approaching this aspect through the perspective of demand, it will increase by $90 \%$ for IT skills [45].

Currently, the energy market is at the stage of entering into digitization of processes already existing in enterprises. It is determined mainly by technical aspects related directly to the nature of the organization's activities and topics related to investments in the energy industry. Thanks to the broadly-defined digitization, internal procedures, instructions, and above all internal and external processes of enterprises, which include, among others, the use of artificial intelligence in servicing suppliers, are subject to change. General digitization raises the standards of security and efficiency of energy systems in Poland and in the world [46].

\section{Materials and Methods}

In the article, literature studies were carried out using the desk research method with the use of secondary sources. The survey was conducted in a Polish company operating in the power industry on 6-30 April 2021. Twenty managers from enterprises operating in the power industry in the Masovian Province participated in the survey, including 13 women $(65 \%)$ and 7 men (35\%). The conducted research was a pilot study and related to the management staff of an enterprise operating in the power industry. The enterprise started operating in 2001. The company sells and supplies electricity to business customers, including railway companies. The age of respondents was as follows: 1 person in the age range of $25-35(5 \%), 17$ people in the age range of $36-45(85 \%)$ and 2 people in the age range of 46-59 (10\%). All respondents have higher education and are employed in a large enterprise (employment of more than 250 people). Figure 2 shows the territory where the quantitative research was carried out.

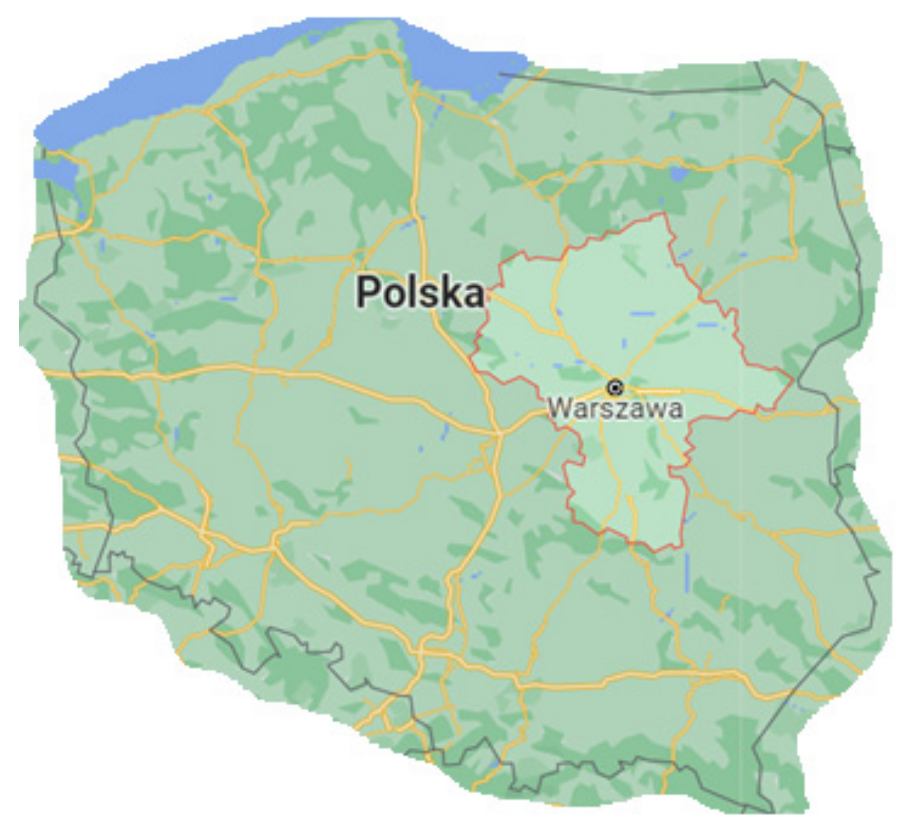

Figure 2. Location of the study performed.

The purpose of the survey was to examine the stage of VUCA awareness at which the managers are and how their employees' perception influences the digital competences of the management staff (analysis of experiences and identification of good practices in the area of supporting the development of digital competences in the context of preparing 
detailed rules for implementing the Digital Poland Operational Program for 2014-2020 and the coordination of thematic objective 2). In [47] the authors, using as research sample executives from Italian companies, analyze through a qualitative study the needs and possible solutions and proposals to reinventing management in the future. In the article below, a comparison was made between the studies conducted in Poland and in Italy.

The survey was conducted in the Google Forms tool, which is used to collect survey results in one place. Google Form is software that is used to manage surveys. The results can be exported to Excel. The respondents fill in the questionnaire anonymously, and the administrator cannot identify them.

People invited to take part in the study received a link to the online questionnaire. Participation in the study was voluntary. The study was a single event with the use of single and multiple-choice questions and statements. Before completing the questionnaire, the respondents did not receive instructions or other additional information necessary to complete it. The respondents who took part in the survey constitute a representative sample of managers who represent the energy sector in the Mazowieckie Voivodeship. The criterion for completing the survey by the respondents was the fact that a given person must be a manager/leader/boss, regardless of the strategic area they work in. Data on age, pays and education level were not the key determinants having a direct impact on the study. Figure 3 presents a diagram of the preparation and conduct of research among the respondents.

Defining the research problem on the basis of literature research.

Preparation of the survey in the form of an online form. The added value of the questionnaire is that it was created on the basis of previous empirical research by the authors and a literature review.

Sending the survey to a randomly selected sample of respondents.

Collecting the survey results

Analyzing the credibility of the results.

Substantive interpretation of the results.

Figure 3. Block diagram presenting the research methodology.

The questionnaire used in the research has a unique nature and was developed on the basis of the authors' previous empirical research and the literature review cited earlier. An article by M. Rzemieniak was an important point of reference [48].

The selection questionnaire consisted of 5 parts. Questions: the first and the second question related to the selection of those statements that largely described the approach of managers to situations and events in their working life and the selection of skills and behaviors that they considered to be the most developed. There was a list of statements in the survey. The respondent had to choose this statement which described his attitudes towards professional life to a greater extent. Questions: the first and the second questions relate to R. Judek's empirical experiences. The third question gave a list of nine competences. 
The respondent had to choose three competences that he considers to be of key importance nowadays. Questions four and five allowed to indicate forms of competence improvement in 2020-2021.

Prior to the reliability analysis, ranks were assigned to eight questions. Questions three and four were not included in the reliability analysis as they are multiple choice questions. Also, the questions regarding the demographics were not included. First, a correlation matrix was generated. Based on this matrix, it was decided that there was no need to reverse the questions. The reliability of the survey was determined using the will makes it possible (Cronbach coefficient). Alpha-Cronbach is the questionnaire reliability coefficient most often used in psychology, understood as the internal consistency of a tool. The Alpha-Cronbach coefficient is 0.80 , which proves that the questions are consistent and are grouped into a latent variable.

\section{Results}

A manager aware of the VUCA world should distinguish when he/she is in a complicated or complex situation or when he/she is facing a complicated and complex problem. Skillful identification of the situation and the problem will make it possible to answer how to effectively manage yourself in VUCA.

"Complicated" statements mean difficult situations that can be dealt with using known patterns of action in accordance with the Deming cycle (plan, do, check, correct). You can prepare for a more or less complicated situation much earlier by arranging the action plan in view of the effect that can be achieved. Experience in this case is an advantage.

"Complex" statements are used in situations where the experience and knowledge of the employee are insufficient. They only serve as a support in the entire decisionmaking process. The development of a schedule of action that is disastrous does not apply. Managers must play the role of an observer and look at situations from a multidimensional perspective.

VUCA means complexity (i.e., situations and problems for which you cannot prepare in advance, but you need to be aware of how to act and deal with chaos). On the other hand, intuition, inner creativity and flexibility for possible changes become reliable.

Table 2 presents the results of the respondents' answers to the question on which statement describes their attitudes towards professional work. Most of the respondents replied that they identify more with the "complicated" statements than the "complex" statements. This means that the managerial staff works on the basis of behaviors and patterns of action they are familiar with. It is easier to manage in a world that is known and the decisions made are conservative. If "complexity" identifies the VUCA world, it means that the studied sample is not fully aware of it. The exception are complex situations such as: Unstable and unpredictable environment ( $80 \%$ of respondents' answers), or There are many moving parts. Many things happen at the same time and the relationship between them is not obvious. (70\% of respondents' answers). Compared to all the statements, complicated ones are distinguished, i.e., "You can create a plan and follow it to achieve success" and complex ones, i.e., "The plan is a challenge, if it is possible to prepare it at all, since the parts are constantly in motion." For this reason, instead of a plan, there is a "next step" in which the answers of the respondents were evenly divided in $50 \%$. As a result, this may mean that more variables need to be considered in terms of planning in order to be effective.

Cognitive readiness determines the perception of the reality and processing stimuli that appear from the external environment. It directly influences the knowledge, skills, and behavior of employees. 
Table 2. Analysis of complicated vs. complex statements.

\begin{tabular}{|c|c|c|c|c|c|}
\hline $\begin{array}{l}\text { "Complicated" } \\
\text { Statement }\end{array}$ & $\begin{array}{l}\text { Respondents' } \\
\text { Answers }\end{array}$ & $\begin{array}{c}{[\%]} \\
\text { Answers }\end{array}$ & $\begin{array}{l}\text { "Complex" } \\
\text { Statement }\end{array}$ & $\begin{array}{l}\text { Respondents' } \\
\text { Answers }\end{array}$ & $\begin{array}{c}{[\%]} \\
\text { Answers }\end{array}$ \\
\hline $\begin{array}{l}\text { You can identify all items or } \\
\text { components and learn how to } \\
\text { work with them. }\end{array}$ & 6 & 30 & $\begin{array}{l}\text { There are many moving parts. } \\
\text { Many things happen at the same } \\
\text { time and the relationship between } \\
\text { them is not obvious. }\end{array}$ & 14 & 70 \\
\hline $\begin{array}{l}\text { You can rethink your way of } \\
\text { acting. The situations can be } \\
\text { analyzed. }\end{array}$ & 13 & 65 & $\begin{array}{l}\text { You need to be able to read the } \\
\text { signals, not the event itself. }\end{array}$ & 7 & 35 \\
\hline $\begin{array}{l}\text { You can create a plan and follow } \\
\text { it to achieve success. }\end{array}$ & 10 & 50 & $\begin{array}{l}\text { The plan is a challenge, if it is } \\
\text { possible to prepare it at all, since } \\
\text { the parts are constantly in motion. } \\
\text { Due to the above, there is a "next } \\
\text { step" instead of a plan. }\end{array}$ & 10 & 50 \\
\hline $\begin{array}{l}\text { Knowledge and experience-they } \\
\text { are valuable and serve you. }\end{array}$ & 16 & 80 & $\begin{array}{l}\text { Knowledge and experience may } \\
\text { no longer be significant. Just } \\
\text { because it once worked, doesn't } \\
\text { mean it will work now. }\end{array}$ & 4 & 20 \\
\hline $\begin{array}{l}\text { The environment seems stable } \\
\text { and predictable. }\end{array}$ & 4 & 20 & $\begin{array}{l}\text { Unstable and unpredictable } \\
\text { environment. }\end{array}$ & 16 & 80 \\
\hline $\begin{array}{l}\text { There is general consent as to the } \\
\text { desired outcome. }\end{array}$ & 7 & 35 & $\begin{array}{l}\text { There are many opinions as to } \\
\text { what the outcome of an action } \\
\text { should be. }\end{array}$ & 13 & 65 \\
\hline Solution-focused approach. & 16 & 80 & $\begin{array}{l}\text { The result is unknown, it is better } \\
\text { to set a direction and take small } \\
\text { steps. Attachment to the expected } \\
\text { result will be disastrous. }\end{array}$ & 4 & 20 \\
\hline $\begin{array}{l}\text { The "complicated" label is mainly } \\
\text { justified for mechanical, technical, } \\
\text { systems as well as tasks that can } \\
\text { be solved logically and linearly. }\end{array}$ & 7 & 35 & $\begin{array}{l}\text { The label "complex" applies to } \\
\text { situations in which people's } \\
\text { feelings, value systems, emotions } \\
\text { and relationships are present. }\end{array}$ & 13 & 65 \\
\hline
\end{tabular}

The chart below shows the results of the respondents' answers, in which they had to assess on a scale from 0 to 10 how well developed the following skills and behaviors are:

- Situational awareness (the ability to view a situation calmly and to the point in times of confusion and chaos);

- Focus (long-term concentration on one task);

- Interpersonal intelligence (the ability to recognize one's own emotions in relation to events in which you are a participant);

- System awareness (noticing connections and relationships in the entire system in which you operate);

- Intuition (understanding without being aware of the process of reaching a problem solution);

- Ability to learn quickly;

- Curiosity (of other people, their perspectives);

- The ability to adapt to a changing environment;

- Tolerance to uncertainty (the ability to remain calm in situations of stress and uncertainty);

- The ability to play the role of an observer;

- Cognitive empathy (the ability to understand the perspective of others) [11].

Figure 4 shows the answers to the question present the current stage of understanding the VUCA world by managers. A score above five points is considered high. The leader is predisposed to "correctly" respond to VUCA. Scores below five points indicate areas on which the manager should work. From the VUCA perspective, the key factors are: situational awareness, curiosity, interpersonal intelligence, the ability to act as an observer, and cognitive empathy. 

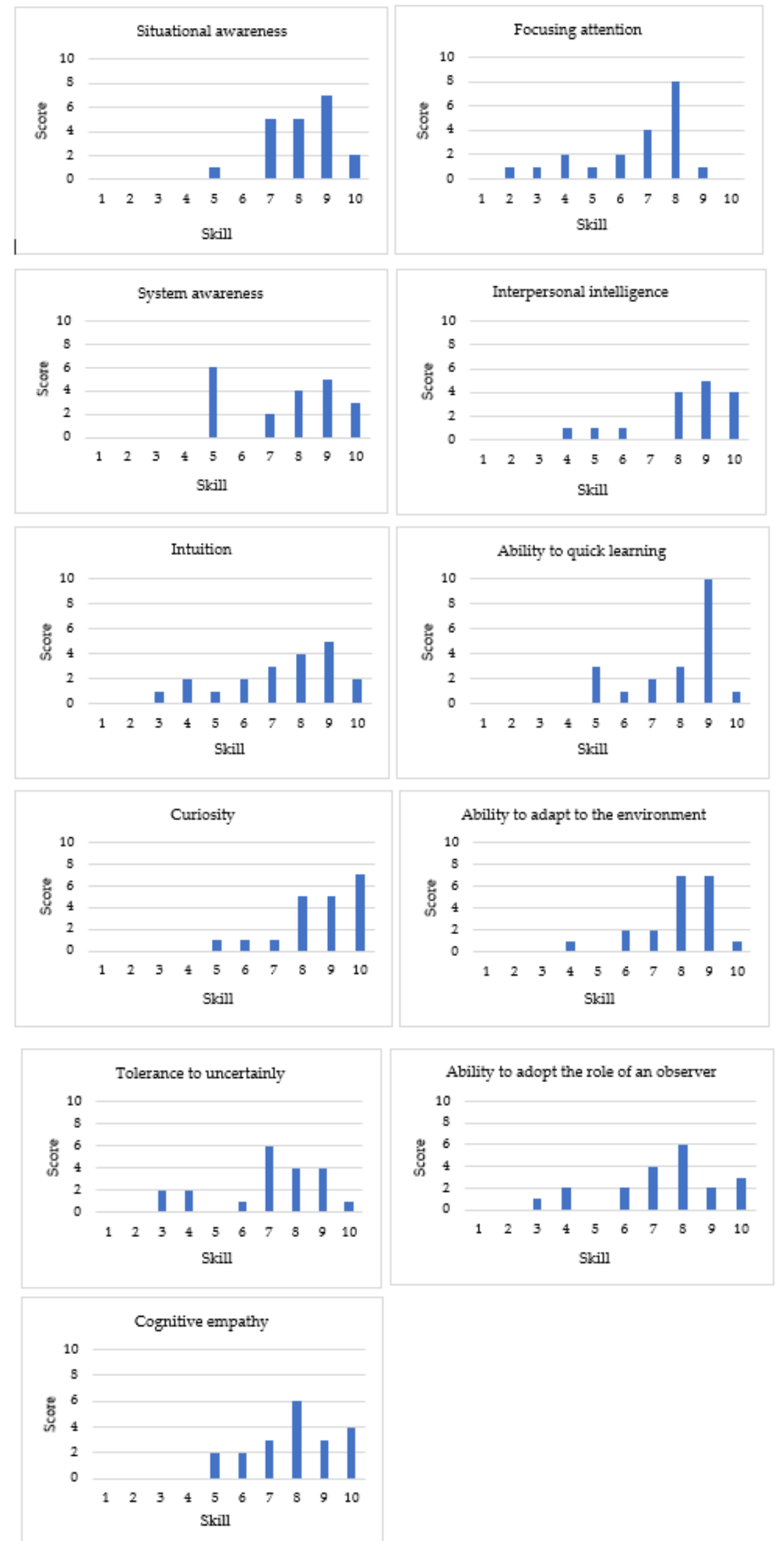

Figure 4. Analysis of managers' behaviors and skills. 
The respondents indicated curiosity (seven responses), interpersonal intelligence (four responses) and cognitive empathy (four responses) on a scale of 10 out of 10 possible points as the most developed skill. The ability to learn quickly (10 responses), situational awareness (seven responses) and the ability to adapt to the changing environment (seven responses) on a 9 out of 10 scale were also rated highly. The respondents assigned less than five points to the following behaviors: focus, intuition, tolerance to uncertainty, and becoming an observer. The highest number of responses was on a scale of six to eight points. The respondents rated their behaviors and skills above the average of five points.

Table 3 presents the respondents' answers to the key behaviors in the VUCA world. The curiosity of other people, employees and their perspectives were rated the highest. The ability to adopt the role of an observer was rated the lowest. The results show that the management staff has a predisposition to react differently to the world of chaos and ambiguity using their strengths, and to work on those that need improvement. Spearman's rank is the coefficient of statistical dependence between random variables. It is used for small research trials. Table 4 shows the calculation of the Spearman's rank correlation coefficient, it was possible to identify and evaluate the correlation between two variables in the case of a small number of research samples.

Table 3. Key behaviors and skills in the VUCA environment.

\begin{tabular}{|c|c|c|c|c|c|c|c|c|c|c|}
\hline \multirow{2}{*}{ Behaviours } & \multicolumn{10}{|c|}{ Respondents' Answers } \\
\hline & 1 & 2 & 3 & 4 & 5 & 6 & 7 & 8 & 9 & 10 \\
\hline Situational awareness & & & & & 1 & & 5 & 5 & 7 & 2 \\
\hline Curiosity & & & & & 1 & 1 & 1 & 5 & 5 & 7 \\
\hline Interpersonal intelligence & & & & 1 & 1 & 1 & 4 & 4 & 5 & 4 \\
\hline Ability to adopt the role of an observer & & & 1 & 2 & & 2 & 4 & 6 & 2 & 3 \\
\hline Cognitive empathy & & & & & 2 & 2 & 3 & 6 & 3 & 4 \\
\hline
\end{tabular}

Table 4. Spearman's index for behavior and skills in the VUCA setting.

\begin{tabular}{lc}
\hline \multicolumn{1}{c}{ Behaviour } & Spearman's Rank Correlation Coefficient- $\mathbf{r}_{\mathbf{s}}$ \\
\hline Situational awareness & 0.24 \\
\hline Focusing attention & 0.18 \\
\hline Interpersonal intelligence & 0.31 \\
\hline System awareness & 0.06 \\
\hline Intuition & 0.54 \\
\hline Ability of quick learning & 0.23 \\
\hline Curiosity & 0.15 \\
\hline Ability to adapt to the environment & 0.20 \\
\hline Tolerance to uncertainty & 0.10 \\
\hline The ability to adopt the role of an observer & 0.40 \\
\hline Cognitive empathy & 0.27 \\
\hline
\end{tabular}

Table 5 shows the results of the three most important competences selected by managers. Competences have been divided into: social, cognitive as well as digital and technical. Most respondents identify the future with digital competence: the ability to develop and adapt digital technologies to the needs of the organization (70\%) and with cognitive competence: the ability to flexibly switch thinking between various problems $(60 \%)$. 
Table 5. Analysis of key competences.

\begin{tabular}{llcc}
\hline \multicolumn{1}{c}{ Competence Type } & \multicolumn{1}{c}{ Competence } & $\begin{array}{c}\text { Respondents } \\
\text { Answers }\end{array}$ & [\%] \\
\hline Digital and technical & Understanding the need to use advanced digital technologies. & 3 & $15 \%$ \\
\hline Social & Identifying the best employees for specific tasks. & 7 & $35 \%$ \\
\hline Cognitive & The ability to come up with unusual and non-obvious ideas. & 7 & $35 \%$ \\
\hline Digital and technical & $\begin{array}{l}\text { The ability to develop and adapt digital technologies to the } \\
\text { needs of the organisation. }\end{array}$ & 14 & $70 \%$ \\
\hline Cognitive & The ability to take the initiative. & 2 & $20 \%$ \\
\hline Social & $\begin{array}{l}\text { The ability to recognise your own emotions and emotions of } \\
\text { other employees. }\end{array}$ & 7 & $10 \%$ \\
\hline Digital and technical & Use of new digital software and tools. & 12 & $35 \%$ \\
\hline Cognitive & $\begin{array}{l}\text { The ability to flexibly switch your thinking between different } \\
\text { problems. }\end{array}$ & 4 & $20 \%$ \\
\hline Digital and technical & Cybersecurity. & $20 \%$ \\
\hline
\end{tabular}

Research has shown that social competences related to choosing employees for individual jobs and empathy towards colleagues are no longer a key element in the VUCA environment. It cannot be said that they are not required, but when compared to digital competences they are second-need skills.

Figure 5 presents the forms of competence improvement among the managerial staff. The vast majority of respondents stated that they mainly use training (75\%) and conferences $(60 \%)$ to improve their knowledge and skills. Mentoring (30\%) can also be distinguished as one of the forms of maintaining knowledge at a certain stable level. Other forms of development are also used, but not as often as those mentioned above.

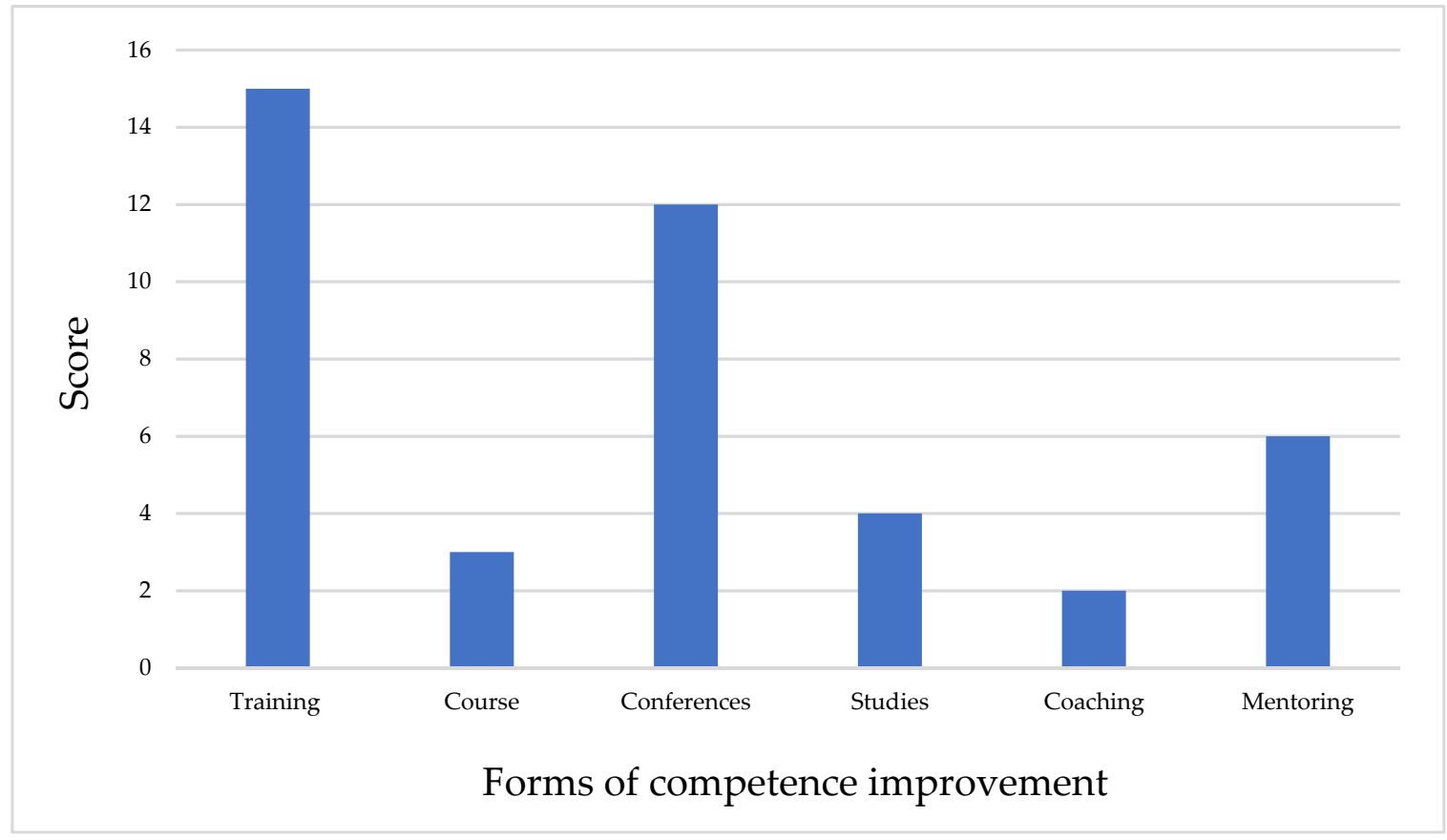

Figure 5. Forms of improving competences.

Figure 6 is related to the frequency of participation of management in training in 2020-2021. Despite the COVID-19 pandemic as well as the training and development transformation, the management staff constantly improves their knowledge, skills and 
experience through active participation in training activities. More than half of the respondents $(45 \%)$ participated in a training one to two times in the surveyed years, while the $35 \%$ of the respondents took part in a training more than four times. The difficult and uncertain situation related to the coronavirus has strengthened the willingness of managers to undertake development activities in any form.

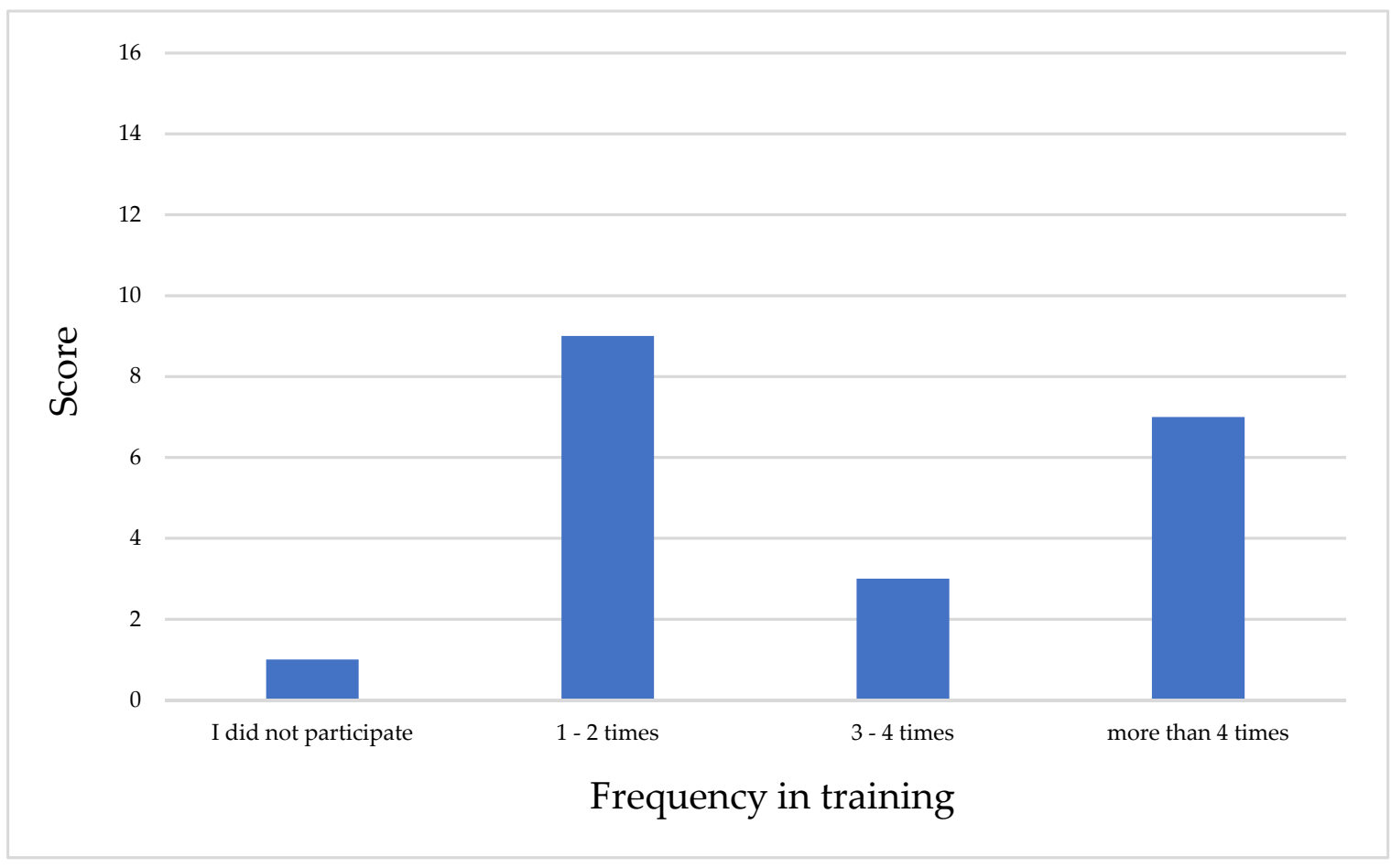

Figure 6. The frequency of participation in training courses in 2020-2021.

Research shows that managers want and feel the need for training, not limiting themselves to mandatory training. The situation requires internal transformation from them as well as moving towards the "competences of the future".

\section{Discussion}

The conducted research showed the existing impact the VUCA environment on digital competences in the managers of the energy industry in the Masovian Province. Competency models are flexible enough to be transformed depending on the influence of the internal and external environment. The changes that will take place in the coming years will be primarily related to the impact of the VUCA environment, which constantly determines the skills and attitudes of employees. The more a company is attached to the broadly-defined "corporate order and governance", the less flexible it will be to introduce digitization of processes. Similar results were obtained by E. Tuleja published in "Visionary Leadership in a turbulent world: thriving in the new VUCA context" [49]. According to the latest research conducted by ManpowerGroup, "companies that have focused on digitization to the greatest extent create the most jobs", and the results are not surprising since as many as $97 \%$ of employers have focused on implementing automation among existing processes or are planning to increase them, with the level of employment unchanged. Relatively fewer (27\%) of organizations intend to increase digitization and automate internal processes. The COVID-19 pandemic is a kind of VUCA that influenced the digitization of enterprises [50]. Research in "The Future of Jobs Report 2020" forecasts that by 2025 there will be a 50:50 division of tasks in the case of human work and machines. As a consequence, it directly translates into the creation of new jobs related to artificial intelligence. To sum up, the future is related to the combination of soft, digital and technical competences, 
which will be a mixture of the employee's unique composition. The digital revolution determines dynamic changes in employees, in particular in their competences and skills as well as their predispositions for quick learning and agile thinking. Research has shown that situational awareness, interpersonal intelligence and a positive attitude to change and digitization are key to guessing the VUCA environment [33]. Also I. Ko and P. Rea showed that the above competences will be key when it comes to the VUCA environment [51]. The digitization of the work environment was also studied by A.S. Mukherjee, who drew similar conclusions [52]. Remote work caused a demand for soft skills, which include: cooperation or openness, according to ManpowerGroup, only $8 \%$ of enterprises try to invest in the above-mentioned competences. This futuristic look was also confirmed by V. Bashi in his research [53]. Also P. Tudorache, L. Ispas and G. Barsan obtained results indicating the hybridization of digital and soft skills. Additionally, the authors drew attention to the fact of developing artificial intelligence (AI) as a factor supporting leaders in the decisionmaking process and increasing organizational flexibility, building their agility to be flexible regardless of the context, or creating the necessary conditions to shape the expeditionary mindset of leaders, more than it was necessary [54]. Machine learning, a subset of artificial intelligence (AI), is also important. It focuses on teaching computers to learn from data and improve as they gain experience. The learning and improvement processes are not programmed. In machine learning, algorithms are trained to find patterns and correlations in large data sets, and to make the best decisions and make predictions based on the results of such analysis. Machine learning systems become more effective over time, and the better they have access to data, the more accurate they are. E.P. Antonacopoulou proposed the wording "VUCA Learning Leadership". VUCA Learning Leadership promotes: learning to feel safe being Vulnerable; learning to remain Unnerved by the unknown, learning to demonstrate Candour and learning to experience. Awakening. These dimensions form an extension of earlier focus in organizational and management learning on socio-materiality and account for sensoriality as a foundation for the 'New Learning Organization' [55]. With high-quality skills at their disposal, leaders will not only be able to understand current decision-making environments, but also visualize those that will emerge in the future, regardless of their physiognomy. This is very important in the energy industry, especially susceptible to changes in the environment [56]. The most important skills were cognitive empathy, curiosity and the ability to adapt to a changing environment, as well as the development of digital processes, which is also confirmed by the research of A. Horstmeyer [28] as well as M. Chatterjee and M. Mohanty [57]. Managers, despite the difficult situation related to the coronavirus, show initiative for individual development by using the available forms of development. In many cases related to the financial or economic crisis, companies have been out of frustration to cut development budgets since they consider training and development to be the least important during the crisis. A very similar situation arose in early 2020, when it was time for the pandemic. Companies cut development budgets massively in order to have reserves and cash for other expenses. As time passed and the situation was accepted, companies unlocked development budgets.

\section{Conclusions}

In the VUCA world professional life is more and more often determined by randomness and coincidence. The world is becoming more and more disordered, resulting in the emergence of unexpected situations and unforeseeable events. The basic challenge that will allow managers to function in the "new reality" is accepting VUCA, and most importantly, of understanding the "reality of change", adapting to new conditions and searching for innovative answers. Business management, which is based on adaptation and readiness to generate new solutions, translates into maintaining satisfactory results of the organization in consequence of surprising events. Due to the influence of VUCA, technical and digital competences will be a continuing trend in HR processes, as well as a basic requirement among the existing managers. VUCA determines advanced competences related to the analysis of systems, as well as their programming and design. One of the universities in 
Singapore has even introduced the UNIS-X Experience Based Learning methodology to prepare its students for future professional skills to cope with the VUCA work environment. The UNIS-X approach incorporates four principles (project-based learning, interdisciplinarity, close collaboration between the faculty and external partners, and active mentoring) in one course. This is to help students as future employees adapt to an ever-changing working environment in an unstable, uncertain, complex and ambiguous (VUCA) working environment. The group of digital competences should be adapted to the changes taking place in the external environment. The development of these skills is required so that an individual can cope well in a dynamic business environment. Digitization and the ability to switch thinking between different situations is determined by the chaos that is provided to managers by VUCA. Due to changing external environment it is required to transform processes in enterprises by imposing one direction-their digitization. The elimination of "manual" human labor and sewing these processes into digital processes enables flexible response to VUCA.

There is an impact of the VUCA environment on the key competences of managers. They have been triggered by uncertain, variable, complex or unclear situations. A manager overwhelmed by these phenomena must change their mindset and perception. Above all they must be prepared for an "uncertain tomorrow". VUCA determines digitization by proving that digitization supports and helps in changing processes or the functioning of the entire enterprise. In a very simple way, you can model processes under the impact of factors flowing from the outside world. If a company is to undergo a digital transformation, it must have employees who are equipped with the appropriate competences and skills. They must have knowledge of the key concepts and processes. VUCA imposes patterns without answering the questions that arise. It leaves managers alone with the decisions they make. The future determined by VUCA will show whether they were right. Digital and cognitive competences are the keys to proper self-management and the conscious selection of leadership strategies in an enterprise. VUCA does not specify what forms of development are to be used by the management. In this case, a full understanding of chaos as well as an intuition guiding the manager is essential. Therefore, training opportunities should be selected individually for each manager. An example is the COVID-19 pandemic, which took the whole world by surprise in an unexpected way. It can be said that it was a test for all enterprises, and above all it was a test for digitization in organizations. The pandemic turns out to be identical to the surroundings of VUCA. The conducted research has shown that managers work according to the patterns they are used to, however, more and more of them notice the variability of elements and the instability of the environment. There is a tendency towards change in the attitudes of employees. We cannot talk about understanding VUCA, but about slowly building awareness of its existence. A limitation in the conducted research was a very narrow sample, which could not fully present the managers' perception.

The research results are very important in identifying digital competences that previously were not of great importance and were not used. It contributes to the development of digital and information technologies that are being intensively implemented in enterprises. The COVID-19 pandemic is cited as an example relating to the VUCA environment. The strong point of the article is the fact that managers identify competences that they will use and develop in the future. They will adapt to new conditions and accept changes in a more understandable way. One of the drawbacks and, at the same time, a limitation of the conducted research is a small research sample.

Novelty results of research are:

- There is an impact of the VUCA environment on the digital competences of managers;

- The development of artificial intelligence has an impact on the development of employees and their competences;

- The VUCA environment can be compared to a "black swan" which comes most often at the wrong time. 
In the perspective of further research, it should be carried out again in about two to three years, in order to examine the perspective of changes in the area of the digital competence model of managers in the VUCA environment. Continuing to work in the 'home office' mode may result in an even greater need to use digital competences. The upcoming future will show which enterprises, despite their bureaucracy, have allowed themselves to be completely transformed.

Author Contributions: Conceptualization, A.N. and M.R.; methodology, A.N.; software, A.N.; validation, A.N. and M.R., formal analysis, A.N. and M.R.; investigation, A.N.; resources, A.N.; data curation, A.N. and M.R.; writing—original draft preparation, A.N.; writing—review and editing, A.N. and M.R.; visualization, A.N.; supervision, A.N. and M.R.; project administration, A.N.; funding acquisition, A.N. and M.R. All authors have read and agreed to the published version of the manuscript.

Funding: This research received no external funding.

Institutional Review Board Statement: Not applicable.

Informed Consent Statement: Not applicable.

Data Availability Statement: Not applicable.

Conflicts of Interest: The Author declares no conflict of interest.

\section{References}

1. Simkova, E.; Hoffmannova, M. Impact of VUCA Environment in Practice of Rural Tourism. Hradec Econ. Days 2021, 11, 746-757. [CrossRef]

2. Pearse, N.J. Change Management in a VUCA World; Emerald Publishing Limited: Bingley, UK, 2017; pp. 81-105.

3. Minciu, M.; Berar, F.A.; Dobrea, R.C. New decision systems in the VUCA world. Manag. Mark. Chall. Knowl. Soc. 2020, 15, 236-254. [CrossRef]

4. Horney, N. Leadership agility: An imperative for a VUCA world. People Strategy 2010, 33, 32-38.

5. Baran, B.E.; Woznyj, H.M. Managing VUCA: The human dynamics of agility. Organ. Dyn. 2021, 50, 11. [CrossRef] [PubMed]

6. Praveen, K.S. HR in VUCA World-A Viewpoint E Insight; Notion Press: Chennai, India, 2018; p. 17.

7. Rodriguez, A.; Rodriguez, Y. Metaphors for today's leadership: VUCA world, millennial and "Cloud Leaders". J. Manag. Dev. 2015, 34, 854-866. [CrossRef]

8. Minciu, M.; Berar, F.A.; Dima, C. The opportunities and threats in the context of the VUCA World. In Proceedings of the 13th International Management Conference on Management Strategies for High Performance (IMC), Bucharest, Romania, 31 October-1 November 2019; pp. 1142-1150.

9. Nandram, S.S.; Bindlish, K.P. Managing VUCA Through Integrative Self-Management; Springer International Publishing: Cham, Switzerland, 2017; p. 3.

10. Waller, R.E.; Lemoine, P.A. Global Higher Education in a VUCA World: Concerns and Projections. J. Educ. Dev. 2019, 3, 73. [CrossRef]

11. Judek, R. VUCA. A Problem or a Challenge? Leaders' Success Strategy; Bona Verba: Warsaw, Poland, $2020 ;$ p. 27.

12. Popova, N.; Shynkarenko, V.; Kryvoruchko, O.; Zeman, Z. Enterprise management in VUCA conditions. Econ. Ann. XXI 2018, 170, 27-31. [CrossRef]

13. Lawrence, K. Developing Leaders in a VUCA Environment; UNC Kenan-Flager Business School: Chapel Hill, NC, USA, $2013 ;$ p. 3.

14. Bennet, N.; Lemoine, G.J. What VUCA Really Means for You. Harv. Bus. Rev. 2014, 92, 27.

15. Bennett, N.; Lemoine, G.J. What a difference a word makes: Understanding threats to performance in a VUCA world. Bus. Horiz. 2014, 57, 311-317. [CrossRef]

16. Beabout, B.R. Turbulence, perturbance, and educational change. Complic. Int. J. Complex. Educ. 2012, 9, 15-29. [CrossRef]

17. VUCA: The New Normal for Talent Management and Workforce Planning. Available online: https://www.ere.net/vuca-thenew-normal-for-talent-management-and-workforce-planning/ (accessed on 28 April 2021).

18. Brodnick, R.; Gryskiewicz, S. Using positive turbulence for planning and change. Plan. High. Educ. 2018, 46, 27-40.

19. Cook, P. Leading in a VUCA World; TTM Associates: London, UK, 2015.

20. Transformative Leadership in the VUCA World. Available online: http://www.production-manager.pl/2020/04/14 / przywodztwo-transformujace-w-swiecie-vuca/ (accessed on 24 April 2021).

21. Baltaci, A.; Balci, A. Complexity leadership: A theoretical perspective. Int. J. Educ. Leadersh. Manag. 2017, 5, 30-58. [CrossRef]

22. What Are the Characteristics of the VUCA World, Including the Current Sanitary Crisis? Available online: https: / www.advuca. $\mathrm{com} /$ post/what-are-the-characteristics-of-the-vuca-world-including-the-current-sanitary-crisis (accessed on 10 May 2021).

23. Stensaker, B.; Frølich, N.; Huisman, J.; Waagene, E.; Scordato, L.; Bótas, P.P. Factors affecting strategic change in higher education. J. Strat. Manag. 2014, 7, 193-207. [CrossRef]

24. Macpherson, C. Embracing Change in a Post Brexit VUCA World; Change \& Strategy International Ltd.: Oxfordshire, UK, 2019. 
25. Green, S.; Page, F.; De'Ath, P.; Pei, E.; Lam, B. VUCA challenges on the design-engineering student spectrum. In Proceedings of the 21st International Conference on Engineering and Product Design Education (E and PDE), Glasgow, UK, 11-13 September 2019.

26. Casey, G.W. Leading in a 'VUCA' world. Volatility. Uncertainty. Chaos. Ambiguity. Fortune 2014, 169, 75-76. [PubMed]

27. Gandhi, L. Human Resource Challenges in VUCA and SMAC Business Environment. ASBM J. Manag. 2017, 10, 1-5.

28. Horstmeyer, A. The generative role of curiosity in soft skills development for contemporary VUCA environments. J. Organ. Chang. Manag. 2020, 33, 737-751. [CrossRef]

29. Rędzińska, A. Deep Listening as a Key Competency of 21st Century Leaders and Entrepreneurs. Coach. Rev. 2018, 10, 100-120. [CrossRef]

30. Mesjasz-Lech, A.; Jelonek, D. The Role of E-Sales in the Establishment of the Information Society. Vision 2025: Education Excellence and Management of Innovations through Sustainable Economic Competitive Advantage; International Business Information Management Association (IBIMA): Madrid, Spain, 2019; pp. 9152-9162.

31. Włoch, R.; Śledziewska, K. Digital Economy. How Technologies Are Changing the World? Publishing House of the University of Warsaw: Warsaw, Poland, 2020.

32. Leadership as an Organization's Competence. Available online: https://www.houseofskills.pl/strefawiedzy/blog/ przywodztwo-jako-kompetencja-organizacji/ (accessed on 24 April 2021).

33. Bader, B.; Schuster, T.; Bader, A.K.; Shaffer, M. The dark side of expatriation: Dysfunctional relationships, expatriate crises, predjudice and a VUCA world. J. Glob. Mobil. Home Expatr. Manag. Res. 2019, 7, 126-136. [CrossRef]

34. Kozierski, R. Business of New Opportunities; Wolters Kluwer: Warsaw, Poland, 2013; p. 17.

35. Lanthaler, W.; Zugmann, J. A New Way of Thinking about Career; Twigger: Warsaw, Poland, 2000.

36. Three Universal Soft Skills That Are Worth Having. Available online: https://www.hays.pl/blog/insights/3-uniwersalnekompetencje-miekkie-ktore-warto-posiadac (accessed on 25 April 2021).

37. Skowron, L.; Gasior, M.; Sak-Skowron, M. The Impact of a Time Gap on the Process of Building a Sustainable Relationship between Employee and Customer Satisfaction. Sustainability 2020, 12, 7446. [CrossRef]

38. Seow, P.S.; Pan, G.; Koh, G. Examining an experiential learning approach to prepare students for the volatile, uncertain, complex and ambiguous (VUCA) work environment. Int. J. Manag. Educ. 2019, 17, 62-76. [CrossRef]

39. Taleb, N.N. Antifragile: Things that Gain from Disorder; Kurhaus Publishing: Warsaw, Poland, 2013.

40. Tudorache, P.; Ispas, L.; Barsan, G. Preparing today's leaders for VUCA environments. In Proceedings of the 8th International Academic Conference on Strategica-Preparing for Tomorrow, Today, Bucharest, Romania, 15-16 October 2020; pp. 263-274.

41. Elkington, R. Ethical Leadership at the Speed of VUCA; Emerald Publishing Limited: Bingley, UK, 2017; pp. 13-37.

42. Breen, J.M. Leadership Resilience in a VUCA World; Emerald Publishing Limited: Bingley, UK, 2017; pp. 39-58.

43. Competences in VUCA World. Available online: https://taptalent.eu/kompetencje-w-swiecie-vuca/ (accessed on 25 April 2021).

44. Włoch, R.; Śledziewska, K. Competences of the Future. How to Shape Them in a Flexible Educational Ecosystem? DELab University of Warsaw: Warsaw, Poland, 2019; p. 10.

45. Skill Shift: Automation and the Future of the Workforce. Available online: https://www.mckinsey.com/featured-insights/futureof-work/skill-shift-automation-and-the-future-of-the-workforce\# (accessed on 8 May 2021).

46. The Future of Digitization in the Energy Sector. Available online: https://transformacja2050.pl/project/cyfryzacja-w-energetyceanaliza/ (accessed on 20 May 2021).

47. D'Amato, V.; Macchi, F. New Governance Model a New Management Model for a VUCA World; IAP Information Age Publishing: Charlotte, NC, USA, 2019; pp. 97-113.

48. Rzemieniak, M.; Wawer, M. Employer Branding in the Context of the Company's Sustainable Development Strategy from the Perspective of Gender Diversity of Generation Z. Sustainability 2021, 13, 828. [CrossRef]

49. Tuleja, E.A. Cultural Intelligence in a VUCA World; Emerald Publishing Limited: Bingley, UK, 2017; pp. $195-227$.

50. Worley, C.G.; Jules, C. COVID-19's Uncomfortable Revelations About Agile and Sustainable Organizations in a VUCA World. J. Appl. Behav. Sci. 2020, 56, 279-283. [CrossRef]

51. Ko, I.; Rea, P. Leading with virtue in the VUCA World. In Advances in Global Leadership; Osland, J.S., Li, M., Mendenhall, M.E., Eds.; Emerald Publishing Limited: Bingley, UK, 2016; Volume 9, pp. 375-397.

52. Mukherjee, A.S. A Digital, VUCA World-The Seventh Principle. In Leading in the Digital World: How to Foster Creativity, Collaboration, and Inclusivity; Management on the Cutting Edge; MIT Press: Cambridge, MA, USA, 2020; pp. 33-39.

53. Mathew, S.G. The Forward Looking Manager in a VUCA World. Vis. J. Bus. Perspect. 2019, 23, 108-109. [CrossRef]

54. Krawchuk, F.; Elkington, R.; Van Der Steege, M.; GlickSmith, J.L.; Breen, J.M. Design Thinking: How to Thrive in a VUCA World; Emerald Publishing Limited: Bingley, UK, 2018; pp. 119-142.

55. Antonacopoulou, E.P. Organisational Learning for and with VUCA: Learning Leadership Revisited. Teoria e Práctice em Administração 2018, 8, 10-32. [CrossRef]

56. Millar, C.; Groth, O.; Mahon, J.F. Management Innovation in a VUCA World: Challenges and Recommendations. Calif. Manag. Rev. 2018, 61, 5-14. [CrossRef]

57. Chatterjee, M.; Mohanty, M. Relationship between Leadership Behavior and Perceived Leadership Effectiveness of Transformational, Transactional and Laissez-faire Corporate Leaders in Kolkata, India in VUCA World-A Comparative Study. Pac. Bus. Rev. Int. 2019, 11, 14-28. 